\title{
In vitro and in situ tests to evaluate the bacterial colonization of cementitious materials in the marine environment
}

\author{
Mahmoud Hayek $^{\mathrm{a}, *}$, Marie Salgues ${ }^{\mathrm{a}}$, Frédéric Habouzit ${ }^{\mathrm{b}}$, Sandrine Bayle ${ }^{\mathrm{c}}$, \\ Jean-Claude Souche ${ }^{\mathrm{a}}$, Klaartje De Weerdt ${ }^{\mathrm{d}}$, Sylvain Pioch ${ }^{\mathrm{e}}$ \\ ${ }^{a}$ LMGC, IMT Mines Alès, Univ Montpellier, CNRS, Alès, France \\ ${ }^{\mathrm{b}}$ INRA, URO050, Laboratoire de Biotechnologie de l'Environnement (LBE), 102 Avenue des Etangs, F-11100, Narbonne, France \\ ${ }^{\mathrm{c}}$ LGEI, IMT Mines Alès, Alès, France \\ ${ }^{\mathrm{d}}$ Norwegian University of Science and Technology NTNU, Department of Structural Engineering, Trondheim, Norway \\ ${ }^{\mathrm{e}}$ UMR 5175 CEFE, Université Paul Valéry, SupAgro, EPHE, Laboratoire Biologie Ecologie Environnement - UPV, Route de Mende, 34000, Montpellier, France
}

\begin{abstract}
A B S T R A C T
Civil engineers have a responsibility to take measures to protect marine biodiversity by selecting more bioreceptive construction materials in the design of marine infrastructure, for better biodiversity conservation. In this study, it was shown that pre-carbonation of cementitious materials accelerates their bacterial colorization by lowering the $\mathrm{pH}$ of their surface. It has been shown both in the laboratory and in-situ tests that the bacterial colonization of cementitious materials is influenced by the $\mathrm{pH}$ and the type of cement. By comparing the bacterial colonization of Portland cement mortars, CEM I, and slag cement, CEM III, mortars, it was found that the CEM III mortars are more bioreceptive than the CEM I mortars. This study presented and verified a novel experimental laboratory approach which can be used to evaluate the bacterial colonization (bioreceptivity) of cementitious materials in marine environment. The approach could be taken up in future recommendations to enable engineers to eco-design more eco-friendly marine infrastructure and develop green-engineering projects.
\end{abstract}

Keywords:

Cementitious materials

Bacterial colonization

Marine environment in-vitro/in-situ tests

Ecological engineering

\section{Introduction}

There is a world concern to develop a new project based on ecological reconciliation, through a "win-win" approach between human and nature [1]. Today, cementitious materials such as concrete are essential materials for the construction of marine structures such as marine ports and coastal structures [2-4]. There is an increasing research effort into ways that coastal infrastructure can be built to meet engineering requirements, while also increasing its value as habitat for marine life to the benefit of both engineering and nature [5-10]. Structures are aimed to be constructed with a minimal impact on the existing environment and with a maximal possible development of new ecological habitat to encourage ecosystems that replace those that may be lost $[11,12]$. Combining engineering techniques and ecological understanding can provide cost-effective ways of maintaining or enhancing biodiversity $[7,13,14]$.

The engineers who design civil engineering structures must carry out intensive investigations to ensure a minimum service life of the structures while respecting the economic constraints [15]. In the marine environment, cementitious materials are exposed to a multitude of actions of different natures (physical, chemical and biological) which can be aggressive towards the material and act synergistically, leading to the deterioration of the structure [15-18]. Although actions of a mechanical and physicochemical nature are generally well understood and are subject to standards and recommendations, the actions of a biological nature are much less considered and often neglected [19]. However, it should be noted that the durability of the material and biological interactions between the material and the environment are interconnected, as degradation of concrete structures has been observed to vary in intensity and rate of appearance and propagation due to the presence of microorganisms [20-23]. The biological interactions between concrete and the marine environment can lead to biodegradation or bioprotection of marine structure [23-25]. Any undesirable change in the properties caused by the activities of living organisms is considered

* Corresponding author. LMGC, IMT Mines Alès, Univ Montpellier, CNRS, 6, avenue de Clavières, 30319, Alès Cedex, France.

E-mail addresses: mahmoud.hayek@mines-ales.fr (M. Hayek), marie.salgues@mines-ales.fr (M. Salgues), frederic.habouzit@inra.fr (F. Habouzit), sandrine. bayle@mines-ales.fr (S. Bayle), jean-claude.souche@mines-ales.fr (J.-C. Souche), klaartje.d.weerdt@ntnu.no (K. De Weerdt), sylvain.pioch@univ-montp3.fr (S. Pioch). 
as biodeterioration of concrete [26]. Microorganisms affect the stability of concrete by contributing to surface erosion, which increases the porosity of the surface and thus reduces the protection of the concrete cover. Increased porosity of the concrete cover leads to more efficient transport of aggressive ions $\left(\mathrm{Cl}^{-}, \mathrm{Mg}^{2+}, \mathrm{OH}^{-}\right)$which can accelerate reinforcement corrosion, cracking, flaking and other damage [20,21, 27]. In contrast, microorganisms can also protect the colonized concrete by forming a physical barrier that reduces surface permeability, leading to better durability of the cementitious materials [24,28-32].

In seawater, concrete and any natural or artificial substrata quickly become fouled [33-35]. The term "fouling" is defined as the colonization of any solid surface, living or dead, natural or artificial by living organisms in a marine or wet environment [36-39]. This colonization can be divided into two main stages, micro-fouling and macro-fouling, which are characterized respectively by the formation of bacterial biofilm on the surface and the adhesion of macro-organisms such as algae, barnacles and larvae (macro-fouling) (Fig. 1) [14,34,40].

Within minutes of immersing, organic molecules and particles are adsorbed onto the surface of cementitious materials, which is later colonized by bacteria that form a biofilm. Bacterial biofilms are composed of one or multiple bacteria species attached to the substratum (and to each other) and encased within a matrix of extracellular polymeric substances (EPS) [33]. The formation of bacterial biofilm involves i) the reversible and irreversible adhesion of microbial cells to the surface of the cementitious material, ii) the growth and maturation of the biofilm with the secretion of EPS, iii) the partial detachment and dispersion of microbial cells. Mature biofilms have complex, three-dimensional structures, which depend on the species composition of the biofilm, bacterial activity and environmental conditions [41-43]. However, bacteria (bacterial biofilm) are the first colonizers that facilitate the adhesion of other organisms such as fungi, microalgae, macroalgae and invertebrates [44-47]. Fouled structure is characterized by the thickness, density, structure, composition, bioadhesive strength and weight of fouling organisms (Fig. 1).

Understanding the interactions between microorganisms and cementitious materials is crucial and constitutes a fundamental step towards more durable, safer and higher quality structures in many contexts [30,48-50]. However, as mentioned, the material's bioreceptivity (ability to be colonized by living organisms) is determined by the nature and the physico-chemical properties of the surface $[48,51]$ : the chemical composition [52-55], roughness [56,57], porosity [57-59], hydrophobicity [53,60-62], and $\mathrm{pH}[57,63]$. In the marine environment, additional studies are necessary to determine the different factors that can influence the biocolonization of cementitious materials. The main factors seem to be the $\mathrm{pH}$, the chemical composition and the surface roughness [62,64-66].

In order to study the influence of the type of cement (chemical compositions) and surface $\mathrm{pH}$ on the bacterial colonization of cementitious materials immersed in seawater, this paper presentslaboratory and field experiments allowing quantification of bacterial biofilm formed on cementitious materials with different cement and surface $\mathrm{pH}$. The longer-term objective of this study is to develop an experimental approach that could help civil engineers to design green-marine structures by specifying the type and physicochemical characteristics of cementitious material to be used.

\section{Materials and methods}

\subsection{Preparation of cementitious materials specimens}

Three types of cementitious materials were produced: concrete, cement paste and mortar. Table 5 gives an overview over the investigated samples, the pre-treatment, the exposure and the techniques applied.

\subsubsection{Preparation of cement paste specimens}

In order to test our laboratory experimental approach, a Portland cement paste was prepared by mixing (mixer, $500 \mathrm{rpm}$ for $60 \mathrm{~s}$ and 1000 $\mathrm{rpm}$ for $30 \mathrm{~s}$ ) in a ratio w/c of 0.5 , Portland cement (Portland cement CEM I 52,5 N PM ES) and water. After mixing, the cement pastes were cast in cylindrical molds with $2.2 \mathrm{~cm}$ diameter and $2 \mathrm{~cm}$ height and were kept 7 days at $20^{\circ} \mathrm{C}$ in a laboratory room. Then, the cement pastes were demolded and placed for 7 days in the laboratory room at $20^{\circ} \mathrm{C}$.

\subsubsection{Preparation of mortar specimens}

In order to study the influence of the type of cement and surface $\mathrm{pH}$ on the natural bacterial colonization of mortars, four types of mortar specimens were prepared; two with CEM I Portland cement (Portland cement CEM I 52.5 N PM ES), and two with CEM III (composed of $60 \%$ of ground granulated blast-furnace slag NF EN 15167-1, provided by Ecocem, $\mathrm{N}^{\circ}$ CAS: 65996-69-2). Table 1 shows the major constituents of this type of slag.

The mortar had a water-cement-ratio $(\mathrm{w} / \mathrm{c})$ of 0.5 and was composed of $450 \mathrm{~g}$ cement and $1350 \mathrm{~g}$ sand (see Table 2). After mixing, the mortars were cast in cylindrical molds with $5.5 \mathrm{~cm}$ diameter and $6 \mathrm{~cm}$ height and were kept sealed with a lid at $20^{\circ} \mathrm{C}$. After 7 days of hardening, mortar samples with a diameter of $2.8 \mathrm{~cm}$ and a height of $3 \mathrm{~cm}$ were cut out from mortar cylinders. In order to reduce excessive leaching of $\mathrm{Ca}(\mathrm{OH})_{2}$ during the test, the cut mortar specimens were first immersed in distilled water for at least 14 days with weekly water replacement. This preleaching has the role of lowering the $\mathrm{pH}$ of the surface and then makes easier material colonization.

After the pre-leaching procedure, half of the mortar samples were placed at $20{ }^{\circ} \mathrm{C}$ in an aerated chamber for 7 days to obtain carbonated mortar samples (Table 2). The surface $\mathrm{pH}$ was evaluated using $\mathrm{pH}$ paper

Table 1

Chemical composition of the blast furnace slag (traces of $\mathrm{TiO}_{2}, \mathrm{Na}_{2} \mathrm{O}$ and $\mathrm{K}_{2} \mathrm{O}$ are also detected in the slag [67]).

\begin{tabular}{ll}
\hline Component & Percentage (\%) \\
\hline $\mathrm{CaO}$ & $35-48$ \\
$\mathrm{SiO}_{2}$ & $32-41$ \\
$\mathrm{Al}_{2} \mathrm{O}_{3}$ & $9-18$ \\
$\mathrm{MgO}$ & $1-9$ \\
$\mathrm{MnO}_{2}$ & $0.4-0.7$ \\
$\mathrm{Fe}_{2} \mathrm{O}_{3}$ & $0.2-3$ \\
$\mathrm{SO}_{3}$ & $0.4-1$ \\
\hline
\end{tabular}

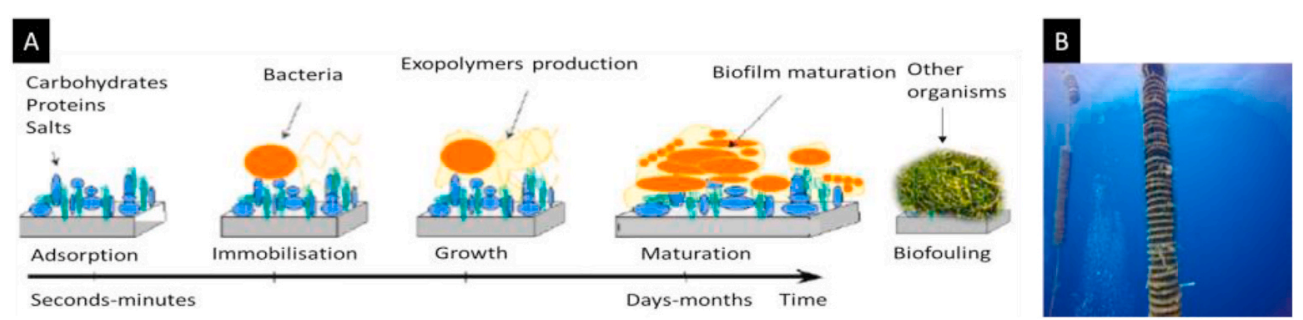

Fig. 1. Biofouling in the marine environment. (A) Schematic representation of marine biofouling formation [40]. (B) Photo of marine biofouling [14]. 
Table 2

Types and compositions of mortar specimens investigated in this study.

\begin{tabular}{|c|c|c|c|c|c|c|c|}
\hline Mortar specimen & Cement & $\mathrm{w} / \mathrm{c}$ & CEM I (g) & Ecocem $(g)$ & Water (g) & Sand $(\mathrm{g})$ & pre-treatment \\
\hline $1 \mathrm{C}$ & CEM I & 0.5 & 450 & 0 & 225 & 1350 & $\begin{array}{l}14 \text { days in distilled water } \\
7 \text { days in aerated chamber }\end{array}$ \\
\hline $1 \mathrm{NC}$ & & & & & & & 14 days in distilled water \\
\hline $3 \mathrm{C}$ & CEM III & 0.5 & 180 & 270 & 225 & 1350 & $\begin{array}{l}14 \text { days in distilled water } \\
7 \text { days in aerated chamber }\end{array}$ \\
\hline $3 \mathrm{NC}$ & & & & & & & 14 days in distilled water \\
\hline
\end{tabular}

(described below) and the phenolphthalein solution [68]. When applied, phenolphthalein indicators give a pink color to the non-carbonated surface while the surface becomes colorless if it is carbonated.

Table 2gives an overview of the four types of mortar specimens: 1carbonated CEM I, 2- Non-carbonated CEM I, 3- carbonated CEM III, 4Non-carbonated CEM III. The abbreviation, cement type used, composition and pre-treatment for the four specimens are specified.

\subsubsection{Preparation of concrete specimens}

Concrete specimens used in this study (Table 5) were extracted from concrete discs (diameter $11 \mathrm{~cm}$ and height $7 \mathrm{~cm}$ ) already prepared in 2016 by Souche et al. $[14,56]$. Table 3 shows information regarding the composition of the concrete. The concrete was prepared with water to cement ratio of 0.6, a Portland cement CEM I $52.5 \mathrm{~N}$ PM ES (the same type of cement is used in mortar and cement paste samples), sand $(0 / 4$, Languedoc Roussillon Matériaux, LRM), a natural silica-limestone gravel (5.6/11.2, LRM), and a superplasticizer with a high water reducing properties.

The concrete samples used in this study (diameter $2 \mathrm{~cm}$ and height $0.3 \mathrm{~cm}$ ) were obtained by coring (with a crown of $2.2 \mathrm{~cm}$ ) and sawing the concrete discs. Each concrete sample obtained after sawing was inspected and selected to be representative (presence of paste and aggregates). The samples obtained from the end of the discs were considered as carbonated samples and the rest of the cylinder was considered as non-carbonated. The samples obtained were hermetically stored in sealed tubes for 1 day and then emerged in seawater. As was the case for mortars, the $\mathrm{pH}$ of the concrete surface was evaluated using $\mathrm{pH}$ paper and the $\mathrm{pH}$ indicator phenolphthalein. The phenolphthalein test revealed that the sawn samples at the end of the discs are carbonated, which is not the case with the sawn samples from the rest of the discs (Fig. 2).

\subsection{Biofilm laboratory test}

Biofilm laboratory test was performed on both concrete and cement paste samples. In both cases, the medium used was seawater recovered from the IFREMER station at Palavas (Biology Research Unit for exploited marine organisms) in sterile glass bottles (autoclave, $121{ }^{\circ} \mathrm{C}$ for $15 \mathrm{~min}$ ). The chemical composition of this seawater resembles to that of the Mediterranean Sea (Table 4).

In the case of concrete, two types of samples were used, carbonated and non-carbonated concrete, while in the case of cement paste the variable was the medium used; natural and sterile seawater (natural seawater autoclaved by an autoclave at $121{ }^{\circ} \mathrm{C}$ for $15 \mathrm{~min}$ ). An overview of the samples prepared, how they are exposed, and how they are investigated is proposed in Table 5.

Table 3

Composition of concrete prepared in 2016 by Souche et al. [56].

\begin{tabular}{lll}
\hline Compound & Density $\left(\mathrm{kg} / \mathrm{m}^{3}\right)$ & Quantity $\left(\mathrm{kg} / \mathrm{m}^{3}\right)$ of concrete \\
\hline CEM I 52.5 N PM ES & 3.19 & 333.3 \\
sand $(0 / 4)$ & 2.62 & 827.0 \\
Gravel (5.6/11.2) & 2.56 & 961.0 \\
Superplasticizer & 1.06 & 2.4 \\
Water & 1.00 & 220.3 \\
\hline
\end{tabular}

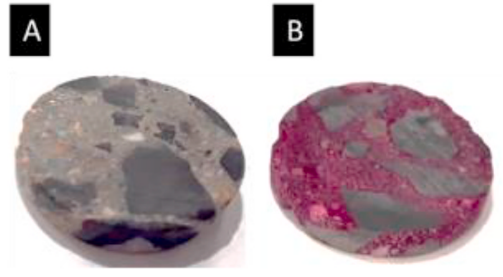

Fig. 2. Phenolphthalein tests on the surface of the concrete samples obtained after sawing. (A) Sample taken from the end of the concrete disc. (B) Sample taken from the rest of the concrete disc.

Table 4

Main ionic species present in the Mediterranean seawater [69].

\begin{tabular}{llllllll}
\hline Ionic species & $\mathrm{Cl}^{-}$ & $\mathrm{SO}_{4}^{2-}$ & $\mathrm{Br}^{-}$ & $\mathrm{Na}^{+}$ & $\mathrm{Mg}^{2+}$ & $\mathrm{Ca}^{2+}$ & $\mathrm{K}^{+}$ \\
\hline Concentration (g/L) & 17.8 & 2.5 & 0.2 & 10.0 & 1.5 & 0.4 & 0.3 \\
\hline
\end{tabular}

To carry out this test, sterile samples of concrete or cement paste (sterilized by autoclave at $121{ }^{\circ} \mathrm{C}$ for $15 \mathrm{~min}$ ) were deposited on the bottom of the $250 \mathrm{ml}$ sterile Erlenmeyer flasks (Duran, Dutscher 092049) containing $50 \mathrm{ml}$ of seawater (4 samples/Erlenmeyer flask) [29]. The Erlenmeyer flasks, sealed with caps (screw cap GL45 with Polytetra-Fluorethylene filter membranes), were then incubated at $20^{\circ} \mathrm{C}$ and $80 \mathrm{rpm}$ to ensure the oxygenation of the medium which is necessary for the growth of microorganisms. After each incubation period $(0,1,2$, $8,10,15,25$ and 35 days), the samples were recovered from the Erlenmeyer flasks and were gently rinsed three times with $1 \mathrm{ml}$ of sterile seawater to remove non-adhered microorganisms from their surfaces. Then, the adhering bacteria were detached from the surface using an ultrasonic bath (Bandelin SONOREX ${ }^{\mathrm{TM}}$ ) for $10 \mathrm{~min}$ at $20^{\circ} \mathrm{C}$ (the samples are placed in sterile tubes containing sterile seawater and the tubes are immersed in the ultrasonic bath). The obtained solution was diluted using sterile seawater. Then, $100 \mu$ of diluted solution were spread on plates containing Marine Agar (Dutscher, 490614). These plates were then incubated at $20{ }^{\circ} \mathrm{C}$ and colony count was performed at least $72 \mathrm{~h}$. The results are expressed as colony forming units per $\mathrm{cm}^{3}$ of cementitious materials $\left(\mathrm{CFU} / \mathrm{cm}^{3}\right)$. This biofilm quantification method known as "culture-based methods" is widely used in the literature [25,70,71]. In this method, the culture medium has a major impact on microorganism growth. We used in this study the Marine Agar, a medium which is widely used for the culture of marine bacteria [43,72,73].

\section{3. $\mathrm{pH}$ measurement}

$\mathrm{pH}$ measurements of the seawater and the surface of the cementitious materials were performed using $\mathrm{pH}$ electrode (Hanna instrument, HI1230, accuracy $0.1 \mathrm{pH}$ unit) and $\mathrm{pH}$ indicator paper (Whatman, 0.0 to 14.0 , accuracy $1 \mathrm{pH}$ unit) respectively. In the case of the $\mathrm{pH}$ measurement of seawater, the $\mathrm{pH}$ electrode was rinsed thoroughly with distilled water before being dipped in a well-agitated seawater $(30 \mathrm{ml})$. The $\mathrm{pH}$ value was noted when the $\mathrm{pH}$ reading is stable. In the case of cementitious materials, one $\mathrm{ml}$ of ultra-pure water (Milli-Q water) was added to the surface of the sample. After $1 \mathrm{~min}$, the $\mathrm{pH}$ paper was deposited on the 
Table 5

Results of the laboratory and in-situ tests.

\begin{tabular}{|c|c|c|c|c|c|c|c|c|}
\hline Test & Type of samples & $\begin{array}{l}\text { Storage before } \\
\text { immersion }\end{array}$ & $\begin{array}{l}\mathrm{pH} \\
\text { at } \\
\mathrm{T} 0\end{array}$ & $\begin{array}{l}\text { Duration of lag } \\
\text { phase during } \\
\text { bacterial } \\
\text { colonization } \\
\text { (days) }\end{array}$ & $\begin{array}{l}\text { Maximum } \\
\text { bacterial } \\
\text { colonization } \\
\left(\mathrm{CFU} / \mathrm{cm}^{3}\right)\end{array}$ & $\begin{array}{l}\text { Time to reach } \\
\text { the maximum } \\
\text { (day) }\end{array}$ & $\begin{array}{l}\mathrm{pH} \text { average of } \\
\text { seawater } \\
\text { during } \\
\text { immersion }\end{array}$ & Results \\
\hline $\begin{array}{l}\text { Laboratory } \\
\text { test }\end{array}$ & Cement paste & $\begin{array}{l}7 \text { days in } \\
\text { laboratory } \\
\text { room at } 20^{\circ} \mathrm{C}\end{array}$ & 12 & ND & ND & ND & 11.50 & $\begin{array}{l}\text { Absence of bacterial colonization; it } \\
\text { is impossible do have biocolonization } \\
\text { in the laboratory (closed water } \\
\text { circuit) using non-carbonated or non- } \\
\text { leached samples }\end{array}$ \\
\hline \multirow[t]{2}{*}{$\begin{array}{l}\text { Laboratory } \\
\text { test }\end{array}$} & $\begin{array}{l}\text { Carbonated } \\
\text { concrete } \\
\text { samples }\end{array}$ & $\begin{array}{l}4 \text { years in } \\
\text { laboratory } \\
\text { room at } 20^{\circ} \mathrm{C}\end{array}$ & 8 & 1 & 61711 & 7 & 8.33 & \multirow[t]{2}{*}{$\begin{array}{l}\text { Surface carbonation promotes } \\
\text { bacterial colonization with a lower } \\
\text { latency phase }\end{array}$} \\
\hline & $\begin{array}{l}\text { Non- } \\
\text { carbonated } \\
\text { concrete } \\
\text { samples }\end{array}$ & $\begin{array}{l}4 \text { years in } \\
\text { laboratory } \\
\text { room at } 20^{\circ} \mathrm{C}\end{array}$ & 10 & 7 & 50601 & 24 & 8.71 & \\
\hline \multirow[t]{4}{*}{ In-situ test } & $\begin{array}{l}\text { Carbonated } \\
\text { CEM I mortar } \\
\text { samples }\end{array}$ & $\begin{array}{l}14 \text { days in } \\
\text { distilled water } \\
7 \text { days in } \\
\text { aerated } \\
\text { chamber }\end{array}$ & 7.3 & 1 & 8229 & 15 & 8.23 & \multirow{4}{*}{$\begin{array}{l}\text { Surface carbonation promotes the } \\
\text { attachment and growth of bacterial } \\
\text { biofilm on cementitious materials in } \\
\text { marine environment } \\
\text { The type of cement has a large } \\
\text { influence on the bacterial } \\
\text { colonization of cementitious } \\
\text { materials in marine environment; } \\
\text { CEM III mortar are more bioreceptive } \\
\text { than CEM I mortar }\end{array}$} \\
\hline & $\begin{array}{l}\text { Non- } \\
\text { carbonated } \\
\text { CEM I mortar } \\
\text { samples }\end{array}$ & $\begin{array}{l}14 \text { days in } \\
\text { distilled water }\end{array}$ & 9.3 & 3 & 5378 & 15 & 8.23 & \\
\hline & $\begin{array}{l}\text { Carbonated } \\
\text { CEM III mortar } \\
\text { samples }\end{array}$ & $\begin{array}{l}14 \text { days in } \\
\text { distilled water } \\
7 \text { days in } \\
\text { aerated } \\
\text { chamber }\end{array}$ & 7.3 & 1 & 37538 & 8 & 8.23 & \\
\hline & $\begin{array}{l}\text { Non- } \\
\text { carbonated } \\
\text { CEM III mortar } \\
\text { samples }\end{array}$ & $\begin{array}{l}14 \text { days in } \\
\text { distilled water }\end{array}$ & 8.6 & 3 & 22378 & 8 & 8.23 & \\
\hline
\end{tabular}

surface and the $\mathrm{pH}$ value was evaluated after $30 \mathrm{~s}$ of contact between the $\mathrm{pH}$ paper and the surface $[57,58]$. Then, this $\mathrm{pH}$ was verified using phenolphthalein indicator (goes from colorless to pink at $\mathrm{pH} \geq 9$ ). This method allows evaluating the $\mathrm{pH}$ of the surface and not the $\mathrm{pH}$ of the complete material. It should be noted that this evaluated $\mathrm{pH}$ can be influenced by the biofilm present on the surface. However, the use of phenolphthalein and $\mathrm{pH}$ indicator paper allows the rather qualitative evaluation of the $\mathrm{pH}$ of the surface and does not give an accurate quantification of the $\mathrm{pH}$ of the material [68].

\subsection{Biofilm in-situ test}

Biofilm in-situ test was carried out using the 4 types of mortars. The in-situ exposure site is located at the IFREMER station in Palavas (France). It is a flat basin (polyester, length $6 \mathrm{~m}$ height $0.6 \mathrm{~m}$ and width $2 \mathrm{~m}$ ) with a seawater inlet and outlet, which allows for an open water circuit.

To ensure the correct progress of the experiment and to avoid any type of contamination, the basin was first cleaned and disinfected. Mortar samples sterilized in the laboratory by autoclave were then placed in the basin and completely covered with seawater.

After each incubation time (0, 1, 3, 8, 15 and 45 days), three mortar samples of each mortar type were used to quantify the formation of bacterial biofilm. The bacterial colonization are quantified as described above and the results are presented as colony forming units per $\mathrm{cm}^{3}$ of mortar $\left(\mathrm{CFU} / \mathrm{cm}^{3}\right)$.

\subsection{Statistical analyses}

To evaluate the significance of the different results obtained, statistical analysis was done via GraphPad Prism 5 (GraphPad Software, San Diego, CA, USA) using $t$-test, one-way and two-way ANOVA tests.
Statistical significance was accepted by $\mathrm{P}_{\text {value }}<0.05$ obtained using Bonferroni or Tukey multiple comparison post-tests.

\section{Results and discussion}

\subsection{Biofilm laboratory test using cement paste samples}

Several studies have been dedicated to the development of a laboratory test for the evaluation of the bioreceptivity of cementitious materials [29,61,74-76]. The laboratory test must be reproducible, inexpensive and easy to carry out. It should also discriminate the intrinsic parameters of cementitious materials for biocolonization. The studies carried out are rather focused on building materials with air as an environment, or sewer systems with wastewater as an environment. However, no study to date has been carried out on maritime structures meaning with seawater as environment, as is done in the current study. The bacterial biofilm developed on the surface of paste samples immersed in seawater under laboratory conditions was quantified during 34 days. Since the development of bacterial biofilm is influenced by the alkalinity of the medium and that of the surface to be colonized, the $\mathrm{pH}$ of the surface of the cement paste samples and seawater was measured throughout the experiment. The results obtained are shown in Fig. 3.

\subsection{1. $\mathrm{pH}$ of cement paste surfaces}

The $\mathrm{pH}$ of the surface is very basic already from the start of this test, with a value equal to 11.75 (Fig. $3 \mathrm{~A}$ ). The $\mathrm{pH}$ was also verified using phenolphthalein indicators which gave a pink coloration after contact with the surface of the cement paste indicating a pH higher than 9. The $\mathrm{pH}$ of the pore solution of hydrated cement paste with CEM I ranges generally between 13 and 14 [77]. The measured $\mathrm{pH}$ of the surface is therefore lower than expected. This might be due to the pre-treatment of 

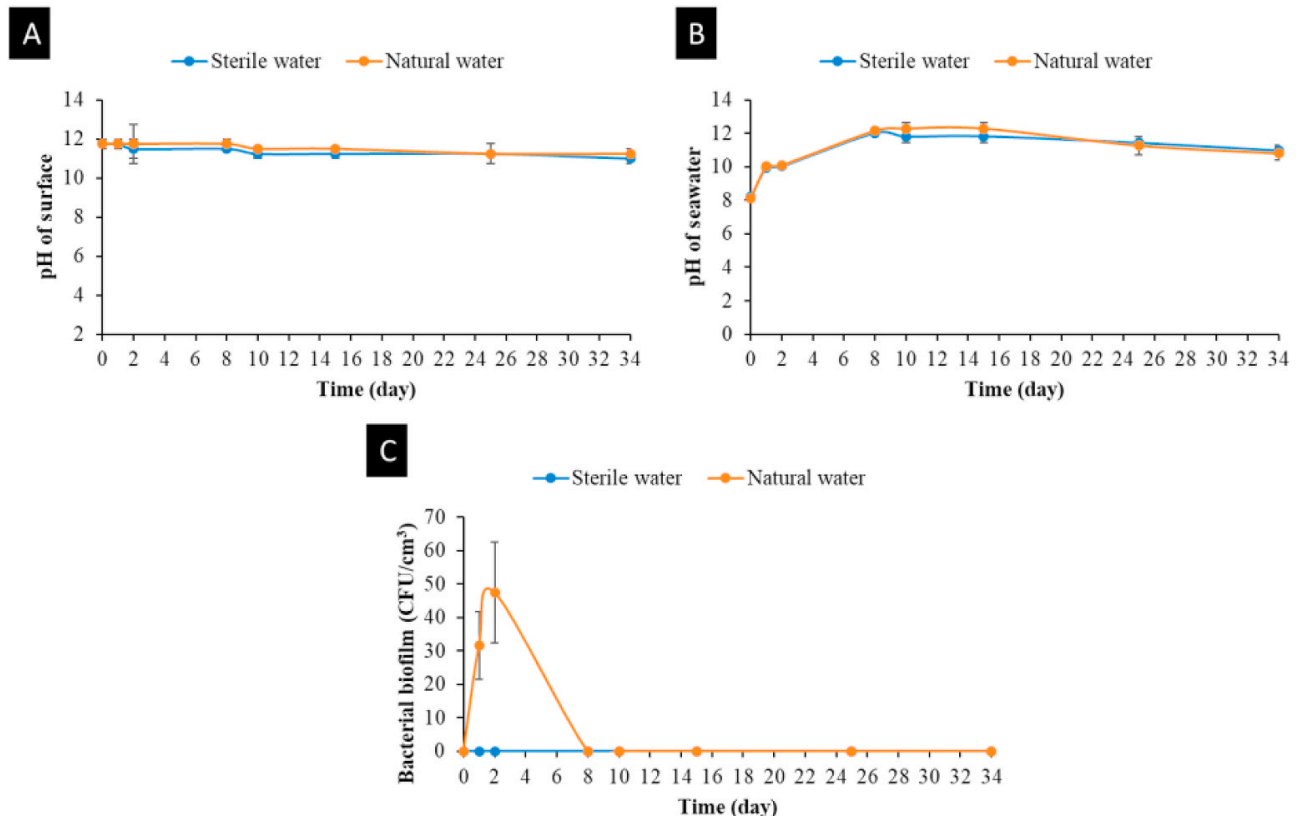

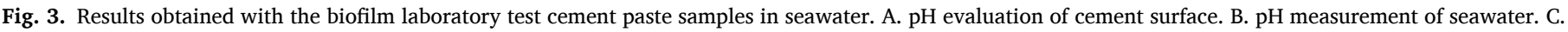
Quantification of bacterial biofilm. Each experiment was performed in triplicate and the error bars present the standard deviation from the obtained values.

the samples.

When cement paste is immersed or in contact with seawater, it will leach due to the high ionic strength of the pore solution of the cement paste compared to the seawater. The $\mathrm{pH}$ of a CEM I paste is generally between 13 and 14 whereas the $\mathrm{pH}$ of seawater varies between 7.5 and 9.0, with an average of around 8.2 [78,79]. Alkali metals such as potassium, as well as calcium and hydroxide ions will leach out of the cement paste which will lead to a decrease in the $\mathrm{pH}$ of the material [80]. However, the $\mathrm{pH}$ of the surface of the cement paste remained almost constant throughout our test. There are two potential reasons for this: (1) the cement paste has been pre-leached during the pre-treatment and reached some kind of steady state prior to the experiment. (2) the volume of the exposure solution (seawater) is constant a rather small (50 ml) which can have lead to rapid saturation of the solution with alkali metals, calcium and hydroxide limiting further leaching during the experiment.

\subsection{2. $\mathrm{pH}$ of seawater}

The "carbonic acid - bicarbonate - carbonate" system is the main $\mathrm{pH}$ buffer for seawater. The $\mathrm{pH}$ of seawater varies between 7.5 and 9.0, with an average of around $8.2[78,79]$. Fig. $3 \mathrm{~B}$ shows that the $\mathrm{pH}$ measured for seawater was 8.2 at the start of the experiment. Due to leaching, the $\mathrm{pH}$ of seawater gradually increases to reach a value of 12 after 8 days of immersion. Then, the $\mathrm{pH}$ remains almost constant throughout the experiment at a value between 11.5 and 12 .

\subsubsection{Quantification of bacterial biofilm}

In their natural or artificial environment, the majority of microorganisms adhere to biotic or abiotic surfaces. This microorganism-surface duality is conditioned by the properties of the substrate, properties of the bacterial surface, and environmental conditions [48]. In seawater, the microorganisms live at $\mathrm{pH}$ values around 8.2 and colonize all natural or artificial surfaces emerged [81,82]. Fig. 3C shows that the adhesion of bacteria to cement pastes was impossible throughout the experiment. This can be explained by the very basic $\mathrm{pH}$ of the seawater and of the cement paste surface (Fig. 3 A and B); a very basic or very acidic $\mathrm{pH}$ can inhibit the biofilm formation by marine microorganisms [83-85].

\subsection{Biofilm laboratory test using concrete samples}

The results obtained with the laboratory test on cement paste show that the $\mathrm{pH}$ of the surface and the seawater alkalinity have a crucial role in the bacterial colonization of cementitious materials under laboratory conditions. Under these conditions, it is impossible to work with nonpre-carbonated or non-pre-leached cementitious materials whose high surface $\mathrm{pH}$ inhibits the adhesion of marine bacteria on the surface.

In order to avoid this high surface $\mathrm{pH}$, another test was carried out in the laboratory under the same conditions as the previous one. This time, the test was carried out using concrete discs naturally cured for 4 years and stored at $20{ }^{\circ} \mathrm{C}$ in a laboratory room [56]. Two types of concrete discs were obtained from these specimens; carbonated (low pH) and non-carbonated (basic $\mathrm{pH}$ ) (see materials and methods). The advantage of working with these samples is to use concrete with a moderate $\mathrm{pH}$ $(\mathrm{pH}<10)$ which does not affect the alkalinity of seawater during immersion.

In order to validate our experimental approach and study the influence of carbonation on the biocolonization of concrete surfaces in the marine environment, carbonated (low pH) and non-carbonated (basic $\mathrm{pH}$ ) concrete samples were incubated in the laboratory (Erlenmeyer flasks) at $20^{\circ} \mathrm{C}$ and $80 \mathrm{rpm}$ in natural seawater. The bacterial biofilm formed on the concrete surface was quantified after $0,1,3,7,10,15,24$, 29 and 60 days. Similarly, the $\mathrm{pH}$ of the concrete surface and the $\mathrm{pH}$ of seawater were determined. The results obtained are shown in Fig. 4.

\subsection{1. $p H$ of concrete surfaces}

The $\mathrm{pH}$ at the surface of the carbonated and non-carbonated samples at T0 is 8 and 10 respectively (Fig. 4 A). The surface has also been sprayed with phenolphthalein indicator, resulting in a pink coloration only for the non-carbonated surface. Then, the $\mathrm{pH}$ measured at $\mathrm{T0}$ is smaller than the known $\mathrm{pH}$ for carbonated and non-carbonated concrete surfaces, 9 and 12 respectively $[86,87]$. This difference can be explained by the aging of these concrete samples prepared and stored in a laboratory room before 4 years (natural carbonation). In contact with air, concrete is under the action of a carbonation reaction (aging) due to $\mathrm{CO}_{2} . \mathrm{CO}_{2}$ from the atmosphere diffuses in gaseous form into the pores of concrete and dissolves in the pore solution, and reacts to $\mathrm{CaCO}_{3}$ thereby lowering the $\mathrm{pH}$ of the pore solution. This phenomenon gradually 

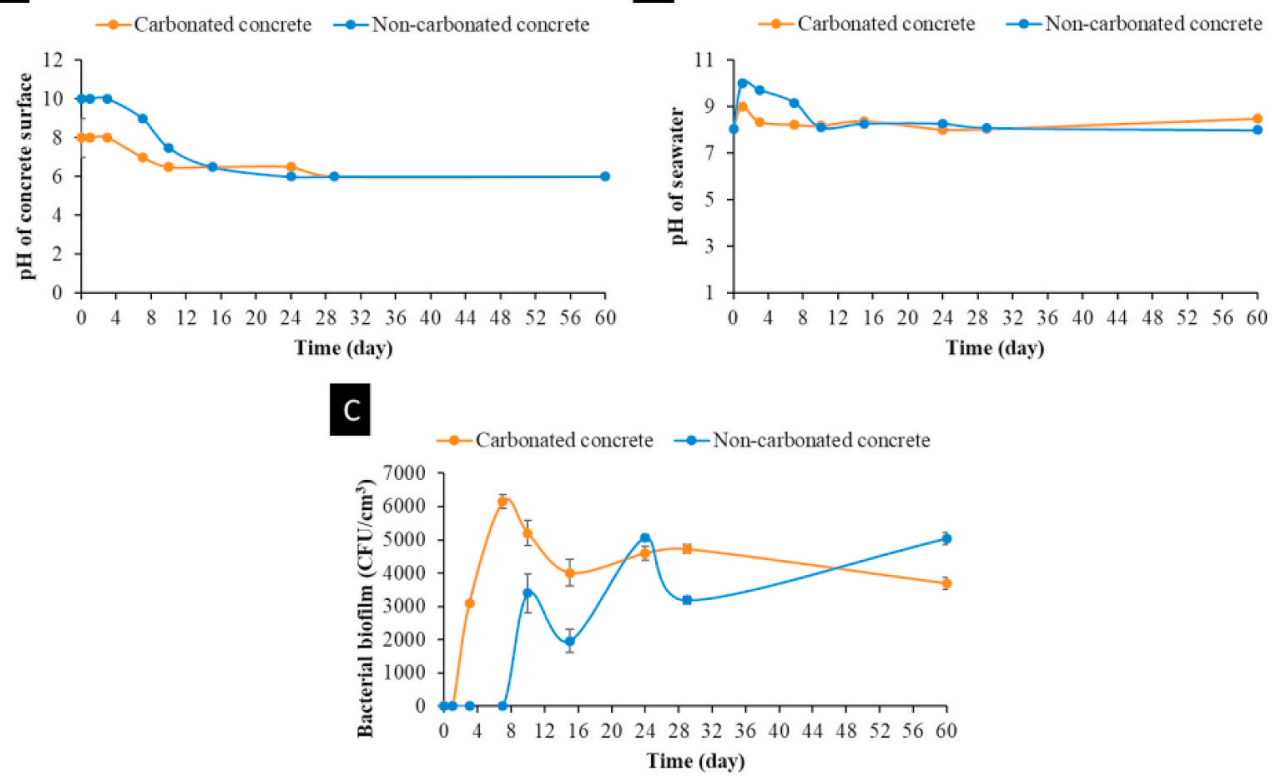

Fig. 4. Results obtained with the biofilm laboratory test using concrete samples. A. pH evaluation of the concrete surface. B. pH evaluation of seawater containing the carbonated and non-carbonated samples. C. Quantification of bacterial biofilm. Each experiment was performed in triplicate and the error bars present the standard deviation of the obtained values.

changes the chemical composition and the $\mathrm{pH}$ of concrete $[84,88,89]$.

Upon immersion, leaching and colonization by bacteria $[80,90]$ lead to a gradually decrease of the $\mathrm{pH}$ of the carbonated and non-carbonated surfaces and reaching a value of 6.5 after 15 days of immersion. Upon further immersion the $\mathrm{pH}$ remains almost constant until the end of the experiment (Fig. 4 A).

\subsection{2. $\mathrm{pH}$ of seawater}

Fig. $4 \mathrm{~B}$ shows that the $\mathrm{pH}$ of the seawater containing non-carbonated samples increases to 10 after 1 day of immersion due to $\mathrm{Ca}(\mathrm{OH})_{2}$ and $\mathrm{KOH}$ release (leaching). Hereafter, the $\mathrm{pH}$ gradually decreases to 8 after 7 days of incubation and then remains almost constant until T60. However, in the case of carbonate samples the $\mathrm{pH}$ remains almost constant throughout the experiment, which indicates that the use of precarbonated samples in the laboratory prevents the increase of the $\mathrm{pH}$ of the seawater and then allows continuous growth of microorganisms.

\subsubsection{Quantification of bacterial biofilm}

Fig. 4C shows that the formation of bacterial biofilm on the carbonated and non-carbonated samples started with a latency phase followed by a phase of growth and accumulation of cells on the surface. These kinetics of the colonization process were also observed by Tran et al. during in vitro and in-situ colonization tests on mortar samples in air $[57,58]$.

In the case of carbonated samples, the formation of bacterial biofilm was spontaneous with an almost non-existent lag phase. The biofilm accumulation on the surface reaches a maximum after 7 days of incubation and then decreases slightly to reach a plateau phase. However, in the case of non-carbonated samples, an induction phase of 7 days was observed and the biofilm formation reached a maximum after 24 days of incubation with a value equal to that in the case of carbonated samples (Fig. 4C). Then, a plateau phase was observed until T60.

The lag period difference between this two sample cases can be explained by the basic (value equal 10) and lower $\mathrm{pH}$ (value equal 8) at T0 of the non-carbonated and carbonated samples respectively. This influence of surface $\mathrm{pH}$ has also been identified in several studies concerning the biocolonization of cementitious materials. These studies showed a higher lag phase in the case of non-carbonated samples $[57,58$,
91]. Similarly, Dooley et al. (1999), Guilbeau et al. (2003), Prieto et al. (2004) showed that carbonation promotes the attachment and growth of microorganisms (algae) during accelerated laboratory tests [92-94].

In addition, a decrease in the surface $\mathrm{pH}$ was found to be necessary for the bacterial biofilm development on non-carbonated samples; the biofilm growth started at 5 days when a decrease in the surface $\mathrm{pH}$ from 10 (T0) to 9 (T5) was observed. These results indicate that carbonation plays a primary role in concrete biocolonization in seawater. This $\mathrm{pH}$ effect of concrete is widely known in the literature: it has been proven that a concrete surface must have a low $\mathrm{pH}$ (carbonated surface) in order to be colonized by microorganisms $[58,85,95]$.

In summary, the presented laboratory test is effective and allows a quick and inexpensive way to test the bioreceptivity of cementitious material intended to be immersed in seawater. With this work, it has been shown that the pre-carbonation of concrete accelerates the development of bacteria on their surface by lowering their $\mathrm{pH}$, which shortens the latency phase observed in the case of carbonated samples.

\subsection{Biofilm in-situ test using mortar samples}

In order to (i) compare the results obtained in the laboratory test with the natural bacterial colonization of cementitious materials (ii) study the influence of the type of cement and surface $\mathrm{pH}$ on the bioreceptivity of cementitious materials, four types of mortar specimens (non-carbonated CEM I, carbonated CEM I, non-carbonated CEM III, carbonated CEM III) were immersed in seawater under natural conditions at IFREMER institute (Palavas - France). The bacterial biofilm formed on the mortar surface was quantified after $0,1,3,8,10,15$ days. At the same time, the $\mathrm{pH}$ of the mortar surface and the $\mathrm{pH}$ of seawater were determined.

\subsection{1. $p H$ of mortar surfaces}

Fig. 5 A shows that the $\mathrm{pH}$ of CEM I mortar samples at T0 is around 9.3 and 7.3 in the case of non-carbonated and carbonated mortars respectively, which indicates that the carbonation and leaching of the samples during their preparation succeeded in lowering the $\mathrm{pH}$ of the mortars (see materials and methods). After immersion, in the case of non-carbonated samples, the $\mathrm{pH}$ decreases gradually and reaches a value 
of 7.5 at T15 due to leaching. However, in the case of the carbonated samples, the $\mathrm{pH}$ of the mortar surface remains nearly constant throughout the experiment.

The CEM I and CEM III mortar samples were prepared in the same way and they were subjected to the same carbonation and leaching conditions. Similarly to the case of CEM 1 samples, the pH of CEM III mortars at T0 is of the order of 8.6 and 7.3 for non-carbonated and carbonated samples respectively (Fig. 5 B). As in the case of CEM I mortars, the $\mathrm{pH}$ of non-carbonated CEM III mortars gradually decreases over time and reaches a value of 7.3 at $\mathrm{T} 15$ while the $\mathrm{pH}$ remains almost constant in the case of carbonated samples.

\subsubsection{Temperature and $\mathrm{pH}$ of seawater}

Fig. $5 \mathrm{C}$ shows that the seawater temperature remained almost constant throughout the experiment with an average of $20.8^{\circ} \mathrm{C}$ (between $21.4{ }^{\circ} \mathrm{C}$ at $\mathrm{T0}$ and $23.5{ }^{\circ} \mathrm{C}$ at T15), which is an optimal temperature for the growth of most marine bacteria [43,96-98]. Temperature is an environmental factor which acts on the biocolonization of cementitious materials [99-102]. Maintaining optimal environmental conditions for the growth of microorganisms facilitates the discrimination of the support parameters (intrinsic parameters of cementitious materials) for biocolonization of cementitious materials. In 2014, Tran et al. compared laboratory and in-situ colonization of carbonated and non-carbonated mortar samples in air. With laboratory tests, they found that carbonation affects colonization, whereas this was not observed in the case of the in-situ tests. They explained this observation by climate conditions unfavorable to microorganisms growth during in-situ tests [57].

Moreover, the $\mathrm{pH}$ of seawater remains constant throughout this test (Fig. 5C). The release of $\mathrm{Ca}(\mathrm{OH})_{2}$ and $\mathrm{KOH}$ resulting from the leaching reaction of the mortar samples after immersion did not affect the $\mathrm{pH}$ stability of seawater because the test was carried out here in an open seawater circuit.

\subsubsection{Quantification of bacterial biofilm}

Fig. 6 shows that the bacterial colonization of CEM I and CEM III mortar samples. It starts with a latency phase followed by a phase of growth and accumulation of cells on the surface, as was the case in the laboratory test. The formation of a bacterial biofilm is faster and higher in the case of carbonated samples compared to the non-carbonated both of CEM I and CEM III mortars. These results confirm the conclusion obtained from the laboratory test; carbonation promotes the attachment and growth of bacterial biofilm on cementitious materials in marine environment.

However, carbonation of cementitious materials leads to a decrease in $\mathrm{pH}$ but also to a change in the mineral phases on the surface such as the appearance of calcium carbonate [103,104]. In the marine environment, the formation of bacterial biofilm is influenced by the presence of divalent cations such as $\mathrm{Mg}^{2+}$ and $\mathrm{Ca}^{2+}$ [105-110]. In general, $\mathrm{Ca}^{2+}$ enhanced the biofilm growth in a dose-dependent manner by binding to the EPS components of the biofilm (especially extracellular DNA), whereas $\mathrm{Mg}^{2+}$ significantly increased the cell growth in biofilm [105, $111]$. We propose that the pre-carbonation of the samples before immersion increases the formation of bacterial biofilm not only by the decrease in $\mathrm{pH}$ but also by the change in the mineral phases on the surface.

\subsubsection{CEM I vs CEM III mortar samples}

Fig. 7 shows that the type of cement has a large influence on the bacterial colonization of cementitious materials in marine environment. The formation of bacterial biofilm is significantly higher in the case of CEM III mortars regardless of the state of carbonation. For example, at 3 days of incubation, the bacterial colonization of carbonated CEM III mortar is approx. 10 times greater than that of carbonated CEM I mortars (Fig. 7 A). At 8 days of incubation, the bacterial colonization of noncarbonated CEM III mortars is about 5 times greater than that of carbonated CEM I mortars (Fig. 7 B). These results are in agreement with the literature in which a similar effect of chemical composition on the biocolonization of cementitious materials has been reported [56,60,64, 106]. In addition, Ahmed showed that cementitious materials prepared with CEM III are more bioreceptive than those formulated by CEM I using laboratory and field-scale tests in river water [112].

In the marine environment, bacterial biofilms are known to interact directly with macro-fouling organisms $[44,106]$ and differences in biofilm community structure and quantity may influence their attachment $[34,113]$. The physical properties of bacterial biofilms, biotic composition of biofilms, and accumulation of chemical compounds, as well as the dynamics of these parameters provide a discriminative mechanism in shaping biofouling communities including algal, larvae and

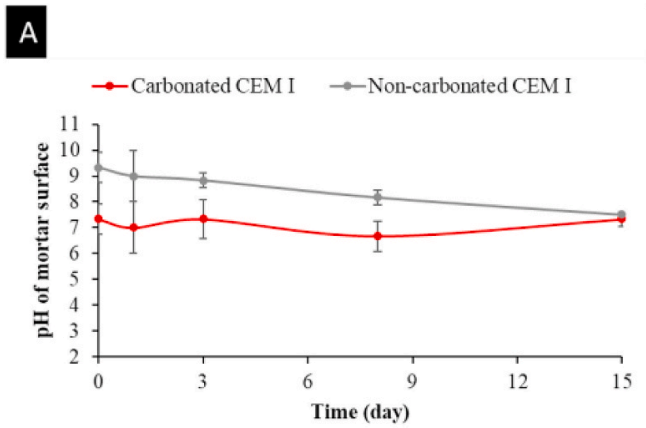

B

$\rightarrow$ Carbonated CEM III $\rightarrow$ Non-carbonated CEM III

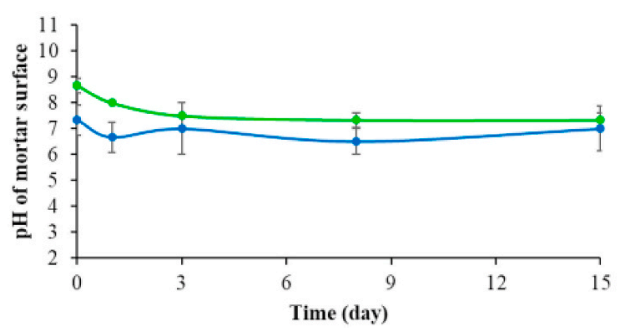

C

$\rightarrow$ Temperature $\rightarrow$ pH

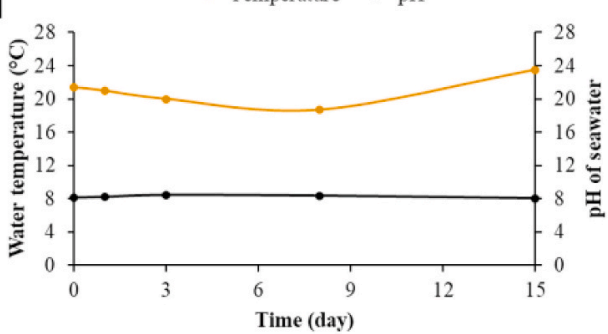

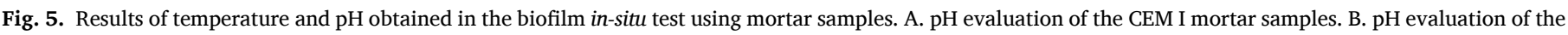

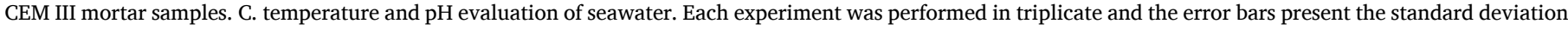
of the obtained values. 
A

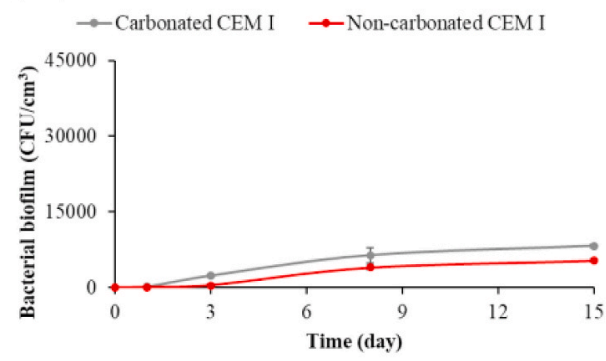

B

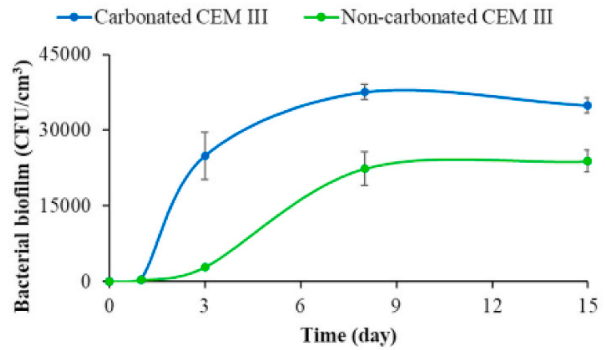

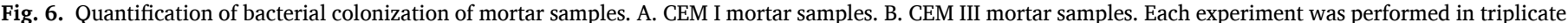
and the error bars present the standard deviation of the obtained values.
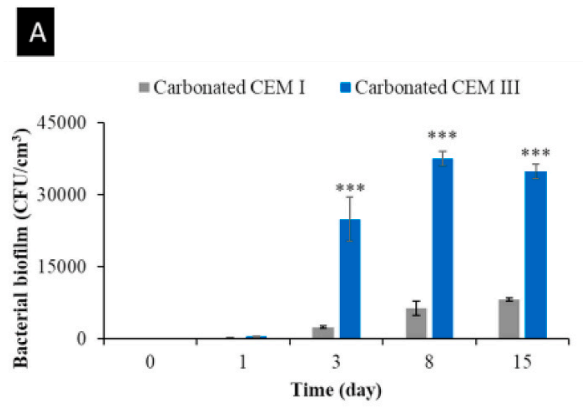

B

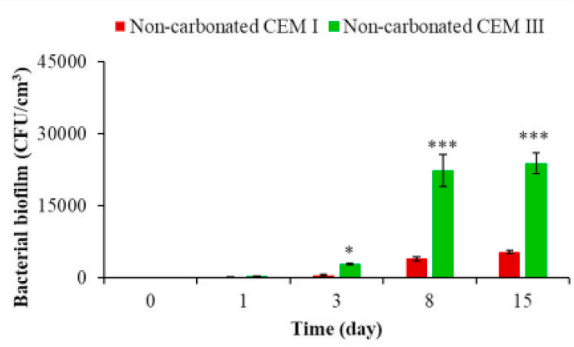

Fig. 7. Formation of bacterial biofilm results using mortar samples. A. Quantification of bacterial biofilm on carbonated CEM I and CEM III mortars. B. Quantification of bacterial biofilm on non-carbonated CEM I and CEM III mortars. Each experiment was performed in triplicate and the error bars present the standard deviation of the obtained values. The experiments highlighted by asterisks were significantly different compared to its control (Bonferroni; *: p $<0.01$, ***: p $<$ $0,001)$ at the indicated time. invertebrate colonization [36,47]. For these reasons, we propose that the chemical composition of submerged cementitious materials can influence not only the quantity of bacterial biofilm, but also macrofouling and subsequently biodiversity in the marine environment. To enhancing marine biodiversity, it is better to manufacture marine structures using CEM III cement.

\subsection{Laboratory versus in-situ tests}

Table 5summarizes the results of the laboratory and field tests.

The first laboratory immersion test was carried out with noncarbonated cement paste samples. The $\mathrm{pH}$ at $\mathrm{T} 0$ of these samples was of the order of 12 which increased the $\mathrm{pH}$ of the seawater and inhibited the growth of bacteria. This test have shown that biocolonization in laboratory immersion tests only occurs on carbonated or leached samples whose $\mathrm{pH}$ is lower than 12 .

The second laboratory immersion test was carried out on samples of long-term cured concrete. The $\mathrm{pH}$ at $\mathrm{T} 0$ of these samples was of the order of 8 and 10 for the carbonated and non-carbonated samples respectively. This low $\mathrm{pH}$ of samples kept the average $\mathrm{pH}$ of seawater at 8.33. Then, the bacteria were in good growth conditions and they colonized the samples. The results obtained with this laboratory immersion test show that the carbonated samples are colonized more quickly and with a greater amount of bacteria.

Finally, in-situ immersion test was carried out with CEM I and CEM III mortar samples. This immersion test confirmed the results obtained with the second laboratory immersion test; surface carbonation promotes the attachment and growth of bacterial biofilm on cementitious materials in marine environment. However, in the case of CEM I mortars, the lag phase is smaller than that observed in the laboratory immersion test for non-carbonated samples (3 days versus 7 days respectively). Furthermore, in the laboratory immersion test the quantity of bacterial biofilm on the surface is higher. These differences can be explained by the different conditions between the laboratory and the field immersion tests; (i) the use of an open seawater circuit for the field immersion test allowed faster leaching of the non-carbonated samples. (ii) The seawater flow allowed a continuous washing of the sample surfaces, which leads to a partial detachment of the bacterial biofilm throughout the experiment [74].

\section{Conclusions}

This study proposes a new fast and reliable laboratory test to control factors that can influence the bacterial colonization of cementitious materials in the marine environment in an easy and inexpensive way. This test allows reproducing, with a simple experiment in Erlenmeyer flasks, the results observed with in-situ tests. The study shows that the laboratory tests have made it possible to mimic the natural environment and to lead to similar conclusions: the carbonation (surface $\mathrm{pH}$ ) and the type of cement play a primary role in cementitious materials colonization by bacteria in the marine environment. Carbonated concrete and mortar are more bioreceptive that the non-carbonated ones in the primary days which is consistent with the literature [54]. The type of cement influences the kinetics and the amount of the development of bacterial biofilm and might have an influence on the biocolonization quality in the marine environment (biodiversity). However, after two weeks, both the materials are colonized in accordance with the study of Jakobsen et al. (2016) [110]. Pre-carbonation of the exposed surface seems to have a stronger beneficial effect on biocolonization compared to the chemical composition of the cement.

Eco-design of marine structures is a major focus for many researchers and construction companies working in marine environment, to enhance durability and also since few years to minimize and mitigate human impacts toward "no net loss" on biodiversity policies [14,114]. These companies have long experience in the field of the design of the marine structures and are seeking to improve the construction in marine ecosystems by for example the inspection of the old structures or the use of innovative concrete "eco-blocks" (e.g. https://www.concretelayer. com). We will collaborate with one of these companies to validate the laboratory test proposed in this paper on an industrial scale by carrying out parallel in vitro and in-situ test on real marine structures. We will also delve deeper into some issues such as the effect of hydrophobicity 
material on biocolonization in marine environments and the effect of formwork oil and curing products on the kinetic of biofilm formation.

\section{Funding sources}

This work was supported by the IMT Mines Ales.

\section{Declaration of competing interest}

The authors declare that they have no known competing financial interests or personal relationships that could have appeared to influence the work reported in this paper.

\section{Acknowledgment}

The authors thank Emmanuel Rezzouk and Sébastien Triplet (IFREMER, Biology Research Unit for exploited marine organisms) for their welcome at the Palavas-les-Flots oceanographic station. The authors thank NTNU, IMT Mines Alès and University Montpellier 3 for their participation or support.

\section{References}

[1] M.L. Rosenzweig, L. Michael, Win-win Ecology: How the Earth's Species Can Survive in the Midst of Human Enterprise, Oxford University Press on Demand, 2003.

[2] S. Dupray, G. Robertshaw, N. Bean, K. Gamst, L'utilisation du béton pour les ouvrages maritimes : synthèse franco-anglaise des bonnes pratiques, in: Xèmes Journées, Sophia Antipolis, Editions Paralia, 2008, pp. 719-728, https://doi.org/ 10.5150/jngcgc. 2008.068-D.

[3] R.T. Allen, Concrete in maritime works, 1972. https://trid.trb.org/view/94285.

[4] J.P. Oleson, C. Brandon, S.M. Cramer, R. Cucitore, E. Gotti, R.L. Hohlfelder, The ROMACONS project: a contribution to the historical and engineering analysis of hydraulic concrete in roman maritime structures, Int. J. Naut. Archaeol. 33 (2004) 199-229, https://doi.org/10.1111/j.1095-9270.2004.00020.x.

[5] M.G. Chapman, A.J. Underwood, Evaluation of ecological engineering of "armoured" shorelines to improve their value as habitat, J. Exp. Mar. Biol. Ecol. 400 (2011) 302-313, https://doi.org/10.1016/j.jembe.2011.02.025.

[6] S. Pioch, K. Kilfoyle, H. Levrel, R. Spieler, Green marine construction, J. Coast Res. (2011) 257-268, https://doi.org/10.2112/SI61-001.24.

[7] S. Pioch, G. Relini, J.C. Souche, M.J.F. Stive, D. De Monbrison, S. Nassif, F. Simard, D. Allemand, P. Saussol, R. Spieler, K. Kilfoyle, Enhancing ecoengineering of coastal infrastructure with eco-design: moving from mitigation to integration, Ecol. Eng. 120 (2018) 574-584, https://doi.org/10.1016/j. ecoleng.2018.05.034.

[8] S. Perkol-Finkel, T. Hadary, A. Rella, R. Shirazi, I. Sella, Seascape architecture incorporating ecological considerations in design of coastal and marine infrastructure, Ecol. Eng. 120 (2018) 645-654, https://doi.org/10.1016/j. ecoleng.2017.06.051.

[9] S. Temmerman, P. Meire, T.J. Bouma, P.M.J. Herman, T. Ysebaert, H.J. De Vriend, Ecosystem-based coastal defence in the face of global change, Nature 504 (2013) 79-83, https://doi.org/10.1038/nature12859.

[10] F. Ferrario, M.W. Beck, C.D. Storlazzi, F. Micheli, C.C. Shepard, L. Airoldi, The effectiveness of coral reefs for coastal hazard risk reduction and adaptation, Nat. Commun. 5 (2014) 3794, https://doi.org/10.1038/ncomms4794.

[11] J.-C. Souche, S. Pioch, M. Salgues, P. Ienny, G. Le Saoût, interaction des ouvrages avec leur environnement. le milieu maritime, collection, Paris, 2018.

[12] M.A. Browne, M.G. Chapman, Ecologically informed engineering reduces loss of intertidal biodiversity on artificial shorelines, Environ. Sci. Technol. 45 (2011) 8204-8207, https://doi.org/10.1021/es201924b.

[13] G.M. Martins, R.C. Thompson, A.I. Neto, S.J. Hawkins, S.R. Jenkins, Enhancing stocks of the exploited limpet Patella candei d'Orbigny via modifications in coastal engineering, Biol. Conserv. 143 (2010) 203-211, https://doi.org/ 10.1016/j.biocon.2009.10.004.

[14] J.-C. Souche, S. Pioch, M. Salgues, K.D. Weerdt, A. Agostini, M. Hayek, De la conception à l'éco-conception des ouvrages maritimes : intégrer la nature au projet d'aménagement maritime, Revue Paralia 12 (2019), https://doi.org/ 10.5150/revue-paralia.2019.n01.

[15] Y. Yi, D. Zhu, S. Guo, Z. Zhang, C. Shi, A review on the deterioration and approaches to enhance the durability of concrete in the marine environment, Cement Concr. Compos. (2020), 103695, https://doi.org/10.1016/j. cemconcomp.2020.103695.

[16] M. Sosa, T. Pérez-López, J. Reyes, F. Corvo, R. Camacho-Chab, P. Quintana, D. Aguilar, Influence of the marine environment on reinforced concrete degradation depending on exposure conditions, Int. J. Electrochem. Sci. 6 (2011) 19.

[17] P.K. Mehta, Durability of concrete in marine environment-A review, SP, 65, 1-20, https://doi.org/10.14359/6343, 1980
[18] M. Collepardi, Concrete durability in a marine environment, in: Proceedings of Canmet/Aci International Conference on Advances in Concrete Technology in the Middle East, UEA, Dubai, 2008, pp. 19-20. Citeseer.

[19] C. Jacob, A. Buffard, S. Pioch, S. Thorin, Marine ecosystem restoration and biodiversity offset, Ecol. Eng. 120 (2018) 585-594.

[20] P. Hughes, D. Fairhurst, I. Sherrington, N. Renevier, L.H.G. Morton, P.C. Robery, L. Cunningham, Microbial degradation of synthetic fibre-reinforced marine concrete, Int. Biodeterior. Biodegrad. 86 (2014) 2-5, https://doi.org/10.1016/j. ibiod.2013.02.015.

[21] P. Hughes, D. Fairhurst, I. Sherrington, N. Renevier, L.H.G. Morton, P.C. Robery, L. Cunningham, Microscopic study into biodeterioration of marine concrete, Int. Biodeterior. Biodegrad. 79 (2013) 14-19, https://doi.org/10.1016/j. ibiod.2013.01.007.

[22] D. Wang, R. Cullimore, Y. Hu, R. Chowdhury, Biodeterioration of asbestos cement (AC) pipe in drinking water distribution systems, Int. Biodeterior. Biodegrad. 65 (2011) 810-817.

[23] Y. Ma, Y. Zhang, R. Zhang, F. Guan, B. Hou, J. Duan, Microbiologically influenced corrosion of marine steels within the interaction between steel and biofilms: a brief view, Appl. Microbiol. Biotechnol. 104 (2020) 515-525, https://doi.org/ 10.1007/s00253-019-10184-8.

[24] T. Chlayon, M. Iwanami, N. Chijiwa, Combined protective action of barnacles and biofilm on concrete surface in intertidal areas, Construct. Build. Mater. 179 (2018) 477-487, https://doi.org/10.1016/j.conbuildmat.2018.05.223.

[25] W. De Muynck, D. Debrouwer, N. De Belie, W. Verstraete, Bacterial carbonate precipitation improves the durability of cementitious materials, Cement Concr. Res. 38 (2008) 1005-1014, https://doi.org/10.1016/j.cemconres.2008.03.005.

[26] M. Sanchez-Silva, V. Rosowsky David, Biodeterioration of construction materials: state of the art and future challenges, J. Mater. Civ. Eng. 20 (2008) 352-365, https://doi.org/10.1061/(ASCE)0899-1561(2008)20:5(352).

[27] S. Wei, Z. Jiang, H. Liu, D. Zhou, M. Sanchez-Silva, Microbiologically induced deterioration of concrete - a Review, Braz. J. Microbiol. 44 (2014) 1001-1007, https://doi.org/10.1590/S1517-83822014005000006.

[28] B.T. Patil, M.R. Gajendragad, G. Ranganna, A.B. Wagh, T. Sudhakaran, Impact of biofouling on corrosion resistance of reinforced concrete. http://agris.fao.org/agr is-search/search.do? recordID=AV20120139400, 1994.

[29] S. Soleimani, B. Ormeci, O.B. Isgor, Growth and characterization of Escherichia coli DH5 $\alpha$ biofilm on concrete surfaces as a protective layer against microbiologically influenced concrete deterioration (MICD), Appl. Microbiol. Biotechnol. 97 (2013) 1093-1102.

[30] S. Perkol-Finkel, I. Sella, Ecologically active concrete for coastal and marine infrastructure: innovative matrices and designs, in: From Sea to Shore ? Meeting the Challenges of the Sea, ICE Publishing, 2014, pp. 1139-1149, https://doi.org/ 10.1680/fsts.59757.124.

[31] M.A. Coombes, H.A. Viles, L.A. Naylor, E.C. La Marca, Cool barnacles: do common biogenic structures enhance or retard rates of deterioration of intertidal rocks and concrete? Sci. Total Environ. 580 (2017) 1034-1045, https://doi.org/ 10.1016/j.scitotenv.2016.12.058.

[32] F. Bartoli, A.C. Municchia, Y. Futagami, H. Kashiwadani, K.H. Moon, G. Caneva, Biological colonization patterns on the ruins of Angkor temples (Cambodia) in the biodeterioration vs bioprotection debate, Int. Biodeterior. Biodegrad. 96 (2014) 157-165, https://doi.org/10.1016/j.ibiod.2014.09.015.

[33] S. Dobretsov, R.M.M. Abed, M. Teplitski, Mini-review: inhibition of biofouling by marine microorganisms, Biofouling 29 (2013) 423-441, https://doi.org/ 10.1080/08927014.2013.776042.

[34] S. Mieszkin, M.E. Callow, J.A. Callow, Interactions between microbial biofilms and marine fouling algae: a mini review, Biofouling 29 (2013) 1097-1113, https://doi.org/10.1080/08927014.2013.828712.

[35] A. Terlizzi, M. Faimali, Fouling on artificial substrata, in: Biofouling, John Wiley \& Sons, Ltd, 2010, pp. 170-184, https://doi.org/10.1002/9781444315462.ch12.

[36] S. Dobretsov, H.-U. Dahms, P.-Y. Qian, Inhibition of biofouling by marine microorganisms and their metabolites, Biofouling 22 (2006) 43-54.

[37] N. Fusetani, Biofouling and antifouling, Nat. Prod. Rep. 21 (2004) 94-104.

[38] H.-C. Flemming, G. Schaule, T. Griebe, J. Schmitt, A. Tamachkiarowa, Biofouling - the Achilles heel of membrane processes, Desalination 113 (1997) 215-225.

[39] N.M. Farhat, L. Javier, M.C.M. Van Loosdrecht, J.C. Kruithof, J.S. Vrouwenvelder, Role of feed water biodegradable substrate concentration on biofouling: biofilm characteristics, membrane performance and cleanability, Water Res. 150 (2019) 1-11, https://doi.org/10.1016/j.watres.2018.11.054.

[40] O.S. Ogunola, O.A. Onada, Anti-biofouling defence mechanism of basibionts (A chemical warfare) - a critical review, J. Environ. Anal. Toxicol. 6 (2016) 1-6, https://doi.org/10.4172/2161-0525.1000380.

[41] L.V. Evans, Structure and function of biofilms, in: Biofilms, CRC Press, 2000, pp. 16-33.

[42] P. Stoodley, K. Sauer, D.G. Davies, J.W. Costerton, Biofilms as complex differentiated communities, Annu. Rev. Microbiol. 56 (2002) 187-209.

[43] M. Hayek, C. Baraquet, R. Lami, Y. Blache, M. Molmeret, The marine bacterium shewanella woodyi produces C8-HSL to regulate bioluminescence, Microb. Ecol. (2019), https://doi.org/10.1007/s00248-019-01454-z.

[44] M. Salta, J.A. Wharton, Y. Blache, K.R. Stokes, J.-F. Briand, Marine biofilms on artificial surfaces: structure and dynamics, Environ. Microbiol. 15 (2013) 2879-2893, https://doi.org/10.1111/1462-2920.12186.

[45] F. Brian-Jaisson, A. Ortalo-Magné, L. Guentas-Dombrowsky, F. Armougom, Y. Blache, M. Molmeret, Identification of bacterial strains isolated from the Mediterranean sea exhibiting different abilities of biofilm formation, Microb. Ecol. 68 (2014) 94-110, https://doi.org/10.1007/s00248-013-0342-9. 
[46] J.-F. Briand, X. Pochon, S.A. Wood, C. Bressy, C. Garnier, K. Réhel, F. Urvois, G. Culioli, A. Zaiko, Metabarcoding and metabolomics offer complementarity in deciphering marine eukaryotic biofouling community shifts, Biofouling 34 (2018) 657-672, https://doi.org/10.1080/08927014.2018.1480757.

[47] S. Dobretsov, D. Rittschof, Love at first taste: induction of larval settlement by marine microbes, Int. J. Mol. Sci. 21 (2020) 731, https://doi.org/10.3390/ ijms 21030731 .

[48] C. Lors, F. Feugeas, B. Tribollet, Interactions Materials - Microorganisms: Concrete and Metals More Resistant to Biodeterioration, EDP sciences, 2019.

[49] M. Ottelé, K. Perini, A.L.A. Fraaij, E.M. Haas, R. Raiteri, Comparative life cycle analysis for green façades and living wall systems, Energy Build. 43 (2011) 3419-3429, https://doi.org/10.1016/j.enbuild.2011.09.010.

[50] K. Perini, M. Ottelé, Designing green façades and living wall systems for sustainable constructions, Int. J. DNE. 9 (2014) 31-46, https://doi.org/10.2495/ DNE-V9-N1-31-46.

[51] S. Pande, S. Shitut, L. Freund, M. Westermann, F. Bertels, C. Colesie, I.B. Bischofs, C. Kost, Metabolic cross-feeding via intercellular nanotubes among bacteria, Nat. Commun. 6 (2015), https://doi.org/10.1038/ncomms7238.

[52] A. Dubosc, Étude du développement de salissures biologiques sur les parements en béton: mise au point d'essais accélérés de vieillissement, PhD Thesis, INSA, Toulouse, 2000.

[53] E. Dalod, Influence de la composition chimique de mortiers sur leur biodétérioration par les algues, phdthesis, Ecole Nationale Supérieure des Mines de Saint-Etienne, 2015, https://tel.archives-ouvertes.fr/tel-01148160/document.

[54] E. Dalod, A. Govin, R. Guyonnet, P. Grosseau, C. Lors, D. Damidot, K.L. Fentiman, Influence of the chemical composition of mortars on algal biofouling, in: $\mathrm{C}$.

H. Mangabhai, R.J. Scrivener (Eds.), International Conference on Calcium Aluminates, IHS BRE Press, Palais des Papes, Avignon, France, 2014, pp. 523-534. https://hal.archives-ouvertes.fr/hal-01053366.

[55] S. Manso, W. De Muynck, I. Segura, A. Aguado, K. Steppe, N. Boon, N. De Belie, Bioreceptivity evaluation of cementitious materials designed to stimulate biological growth, Sci. Total Environ. 481 (2014) 232-241, https://doi.org/ 10.1016/j.scitotenv.2014.02.059.

[56] J.-C. Souche, G. Le Saout, M. Salgues, S. Pioch, Effets de bétons bio-actifs sur la colonisation marine en environnement méditerranéen, Matériaux Tech. 104 (2016) 504.

[57] T.H. Tran, A. Govin, R. Guyonnet, P. Grosseau, C. Lors, D. Damidot, O. Devès, B. Ruot, Influence of the intrinsic characteristics of mortars on their biofouling by pigmented organisms: comparison between laboratory and field-scale experiments, Int. Biodeterior. Biodegrad. 86 (2014) 334-342, https://doi.org/ 10.1016/j.ibiod.2013.10.005.

[58] T.H. Tran, A. Govin, R. Guyonnet, P. Grosseau, C. Lors, E. Garcia-Diaz, D. Damidot, O. Devès, B. Ruot, Influence of the intrinsic characteristics of mortars on biofouling by Klebsormidium flaccidum, in: International Biodeterioration \& Biodegradation, 2012, pp. 31-39, https://doi.org/10.1016/ j.ibiod.2011.10.017.

[59] A. Govin, T.H. Tran, R. Guyonnet, P. Grosseau, C. Lors, D. Damidot, O. Devès, B. Ruot, Ability in biofouling by Klebsormidium flaccidum of mortars: influence of the intrinsic characteristics, in: First International Conference on Concrete Sustainability (ICCS), 2013, pp. 914-919. S3-3-6 pp.

[60] O. Guillitte, Bioreceptivity: a new concept for building ecology studies, Sci. Total Environ. 167 (1995) 215-220, https://doi.org/10.1016/0048-9697(95)04582-L.

[61] D.J. Giannantonio, J.C. Kurth, K.E. Kurtis, P.A. Sobecky, Effects of concrete properties and nutrients on fungal colonization and fouling, Int. Biodeterior. Biodegrad. 63 (2009) 252-259, https://doi.org/10.1016/j.ibiod.2008.10.002.

[62] A.Z. Miller, P. Sanmartín, L. Pereira-Pardo, A. Dionísio, C. Saiz-Jimenez, M. F. Macedo, B. Prieto, Bioreceptivity of building stones: a review, Sci. Total Environ. 426 (2012) 1-12, https://doi.org/10.1016/j.scitotenv.2012.03.026.

[63] S. Manso, G. Mestres, M.P. Ginebra, N. De Belie, I. Segura, A. Aguado, Development of a low pH cementitious material to enlarge bioreceptivity, Construct. Build. Mater. 54 (2014) 485-495.

[64] P. Grosseau, E. Dalod, A. Govin, C. Lors, R. Guyonnet, D. Damidot, Effect of the chemical composition of building materials on algal biofouling. https://hal-emse. ccsd.cnrs.fr/emse-01206843, 2015.

[65] A.Z. Miller, A. Dionísio, L. Laiz, M.F. Macedo, C. Saiz-Jimenez, The influence of inherent properties of building limestones on their bioreceptivity to phototrophic microorganisms, Ann. Microbiol. 59 (2009) 705-713, https:// doi.org/10.1007/ BF03179212.

[66] R.S. McManus, N. Archibald, S. Comber, A.M. Knights, R.C. Thompson, L.B. Firth, Partial replacement of cement for waste aggregates in concrete coastal and marine infrastructure: a foundation for ecological enhancement? Ecol. Eng. 120 (2018) 655-667, https://doi.org/10.1016/j.ecoleng.2017.06.062.

[67] F. Bellmann, J. Stark, Activation of blast furnace slag by a new method, Cement Concr. Res. 39 (2009) 644-650, https://doi.org/10.1016/j. cemconres.2009.05.012.

[68] S. Manso, A. Aguado, A review of sample preparation and its influence on $\mathrm{pH}$ determination in concrete samples, Mater. Construcción 67 (2017) 108, https:// doi.org/10.3989/mc.2017.08515.

[69] A. Vichot, J. Ollivier, La durabilité des bétons. https://www.eyrolles.com/BTP/ Livre/la-durabilite-des-betons-9782859784348/, 2008.

[70] T. Verdier, M. Coutand, A. Bertron, C. Roques, A review of indoor microbial growth across building materials and sampling and analysis methods, Build. Environ. 80 (2014) 136-149, https://doi.org/10.1016/j.buildenv.2014.05.030.

[71] J. Lv, J. Mao, H. Ba, Influence of marine microorganisms on the permeability and microstructure of mortar, Construct. Build. Mater. 77 (2015) 33-40, https://doi. org/10.1016/j.conbuildmat.2014.11.072.
[72] G. Høvik Hansen, R. Sørheim, Improved method for phenotypical characterization of marine bacteria, J. Microbiol. Methods 13 (1991) 231-241, https://doi.org/10.1016/0167-7012(91)90049-V.

[73] A. Díaz-García, A.R. Borrero-Santiago, I. Riba, Implications in studies of environmental risk assessments: does culture medium influence the results of toxicity tests of marine bacteria? Chemosphere 205 (2018) 24-30, https://doi. org/10.1016/j.chemosphere.2018.04.066.

[74] S. Manso, M.Á. Calvo-Torras, N. De Belie, I. Segura, A. Aguado, Evaluation of natural colonisation of cementitious materials: effect of bioreceptivity and environmental conditions, Sci. Total Environ. 512-513 (2015) 444-453, https:// doi.org/10.1016/j.scitotenv.2015.01.086.

[75] G. Escadeillas, A. Bertron, P. Blanc, A. Dubosc, Accelerated testing of biological stain growth on external concrete walls. Part 1: development of the growth tests, Mater. Struct. 40 (2007) 1061-1071, https://doi.org/10.1617/s11527-006-9205 $\mathrm{x}$.

[76] V. Kaushal, M. Najafi, J. Love, Qualitative investigation of microbially induced corrosion of concrete in sanitary sewer pipe and manholes, in: Pipelines 2018, American Society of Civil Engineers, Toronto, Ontario, Canada, 2018, pp. 768-775, https://doi.org/10.1061/9780784481653.086.

[77] K. De Weerdt, M.B. Haha, G. Le Saout, K.O. Kjellsen, H. Justnes, B. Lothenbach, Hydration mechanisms of ternary Portland cements containing limestone powder and fly ash, Cement Concr. Res. 41 (2011) 279-291, https://doi.org/10.1016/j. cemconres.2010.11.014.

[78] I. Halevy, A. Bachan, The geologic history of seawater pH, Science 355 (2017) 1069-1071, https://doi.org/10.1126/science.aal4151.

[79] M. Odier, V. Plichon, Le cuivre en solution dans l'eau de mer: forme chimique et dosage: Étude par polarographie à tension sinusoïdale surimposée, Anal. Chim. Acta 55 (1971) 209-220, https://doi.org/10.1016/S0003-2670(01)82758-6.

[80] Y.-J. Tang, X.-B. Zuo, G.-J. Yin, H. Davoudi, X.-N. Li, Influence of calcium leaching on chloride diffusivity in cement-based materials, Construct. Build. Mater. 174 (2018) 310-319, https://doi.org/10.1016/j. conbuildmat.2018.04.112.

[81] L. John, Marine Biofouling and its Prevention on Underwater Surfaces, 1998, p. 22.

[82] H. Woods, MARINE FOULING AND ITS PREVENTION, 1952.

[83] H. Barberousse, Etude de la diversité des algues et des cyanobactéries colonisant les revêtements de façade en France et recherche des facteurs favorisant leur implantation, 2006.

[84] V. Vishwakarma, R.P. George, D. Ramachandran, B. Anandkumar, U.K. Mudali, Studies of detailed Biofilm characterization on fly ash concrete in comparison with normal and superplasticizer concrete in seawater environments, Environ. Technol. 35 (2014) 42-51, https://doi.org/10.1080/09593330.2013.808249.

[85] M. Olivia, N. Moheimani, R. Javaherdashti, H.R. Nikraz, M.A. Borowitzka, The influence of micro algae on corrosion of steel in fly ash geopolymer concrete: a preliminary study, Adv. Mater. Res. 626 (2013) 861-866. https://doi.org /10.4028/www.scientific.net/AMR.626.861.

[86] C.-F. Chang, J.-W. Chen, The experimental investigation of concrete carbonation depth, Cement Concr. Res. 36 (2006) 1760-1767, https://doi.org/10.1016/j. cemconres.2004.07.025.

[87] E. Possan, W.A. Thomaz, G.A. Aleandri, E.F. Felix, A.C.P. dos Santos, CO2 uptake potential due to concrete carbonation: a case study, Case Studies in Construction Materials 6 (2017) 147-161, https://doi.org/10.1016/j.cscm.2017.01.007.

[88] H. Chang, S. Mu, P. Feng, Influence of carbonation on "maximum phenomenon" in surface layer of specimens subjected to cyclic drying-wetting condition, Cement Concr. Res. 103 (2018) 95-109, https://doi.org/10.1016/j. cemconres.2017.10.005.

[89] X. Liu, D. Niu, X. Li, Y. Lv, Effects of $\mathrm{Ca}(\mathrm{OH}) 2-\mathrm{CaCO} 3$ concentration distribution on the $\mathrm{pH}$ and pore structure in natural carbonated cover concrete: a case study, Construct. Build. Mater. 186 (2018) 1276-1285, https://doi.org/10.1016/j conbuildmat.2018.08.041.

[90] M. Lv, M. Du, A review: microbiologically influenced corrosion and the effect of cathodic polarization on typical bacteria, Rev. Environ. Sci. Biotechnol. 17 (2018) 431-446, https://doi.org/10.1007/s11157-018-9473-2.

[91] C. Grant, Fouling of terrestrial substrates by algae and implications for control - a review, Int. Biodeterior. Bull. 18 (1982) 57-65.

[92] K.M. Dooley, F.C. Knopf, R.P. Gambrell, PH-NEUTRAL CONCRETE for ATTACHED MICROALGAE and ENHANCED CARBON DIOXIDE FIXATION PHASE I, Federal Energy Technology Center, Morgantown, WV (US), Federal Energy Technology Center, Pittsburgh, PA (US), 1999, https://doi.org/10.2172/ 778919.

[93] B.P. Guilbeau, F.P. Harry, R.P. Gambrell, F.C. Knopf, K.M. Dooley, Algae attachment on carbonated cements in fresh and brackish waters-preliminary results, Ecol. Eng. 20 (2003) 309-319, https://doi.org/10.1016/S0925-8574(03) 00026-0.

[94] B. Prieto, B. Silva, O. Lantes, Biofilm quantification on stone surfaces: comparison of various methods, Sci. Total Environ. 333 (2004) 1-7, https://doi.org/10.1016/ j.scitotenv.2004.05.003.

[95] D. Ramachandran, V. Vishwakarma, S.S. Samal, Nanophase modification of concrete for Enhancement of microbial properties and durability: present status and future scope, in: International Conference on Nanoscience, Engineering and Technology, ICONSET 2011), 2011, pp. 636-638, https://doi.org/10.1109/ ICONSET.2011.6167889.

[96] S.O. Stanley, R.Y. Morita, Salinity effect on the maximal growth temperature of some bacteria isolated from marine environments, J. Bacteriol. 95 (1968) 169-173. 
[97] Q. Xu, Z. Zhang, Y. Wang, L. Zhuo, L. Yin, Z. Du, Screening, identification and properties study of marine bacteria producing alkaline cellulase [J], Mar. Sci. 7 (2009).

[98] D. Delille, E. Perret, Influence of temperature on the growth potential of Southern polar marine bacteria, Microb. Ecol. 18 (1989) 117-123, https:// doi.org/ 10.1007/BF02030120.

[99] Y. Nuhoglu, E. Oguz, H. Uslu, A. Ozbek, B. Ipekoglu, I. Ocak, I. Hasenekoglu, The accelerating effects of the microorganisms on biodeterioration of stone monuments under air pollution and continental-cold climatic conditions in Erzurum, Turkey, Sci. Total Environ. 364 (2006) 272-283, https://doi.org/ 10.1016/j.scitotenv.2005.06.034.

[100] H.A. Viles, N.A. Cutler, Global environmental change and the biology of heritage structures, Global Change Biol. 18 (2012) 2406-2418, https:// doi.org/10.1111 j.1365-2486.2012.02713.x.

[101] M.A. Shirakawa, R.G. Tavares, C.C. Gaylarde, M.E.S. Taqueda, K. Loh, V.M John, Climate as the most important factor determining anti-fungal biocide performance in paint films, Sci. Total Environ. 408 (2010) 5878-5886, https:// doi.org/10.1016/j.scitotenv.2010.07.084.

[102] T.H. Tran, Influence of the Intrinsic Characteristics of a Mortar on its Ability to Resist to the Biofouling, Theses, Ecole Nationale Supérieure des Mines de SaintEtienne, 2011. https://tel.archives-ouvertes.fr/tel-00718250.

[103] I.F. Sáez del Bosque, P. Van den Heede, N. De Belie, M.I. Sánchez de Rojas, C. Medina, Carbonation of concrete with construction and demolition waste based recycled aggregates and cement with recycled content, Construct. Build. Mater. 234 (2020) 117336, https://doi.org/10.1016/j.conbuildmat.2019.117336.

[104] A. Pandey, B. Kumar, Investigation on the effects of acidic environment and accelerated carbonation on concrete admixed with rice straw ash and microsilica, Journal of Building Engineering 29 (2020) 101125, https://doi.org/10.1016/j. jobe.2019.101125.

[105] N. Mangwani, S.K. Shukla, T.S. Rao, S. Das, Calcium-mediated modulation of Pseudomonas mendocina NR802 biofilm influences the phenanthrene degradation, Colloids Surf. B Biointerfaces 114 (2014) 301-309, https://doi.org/ 10.1016/j.colsurfb.2013.10.003.
[106] X. He, J. Wang, L. Abdoli, H. Li, Mg2+/Ca2+ promotes the adhesion of marine bacteria and algae and enhances following biofilm formation in artificial seawater, Colloids Surf. B Biointerfaces 146 (2016) 289-295, https://doi.org/ 10.1016/j.colsurfb.2016.06.029.

[107] G.G. Geesey, B. Wigglesworth-Cooksey, K.E. Cooksey, Influence of calcium and other cations on surface adhesion of bacteria and diatoms: a review, Biofouling 15 (2000) 195-205, https://doi.org/10.1080/08927010009386310.

[108] K. De Weerdt, H. Justnes, The effect of sea water on the phase assemblage of hydrated cement paste, Cement Concr. Compos. 55 (2015) 215-222, https://doi. org/10.1016/j.cemconcomp.2014.09.006.

[109] K. De Weerdt, D. Orsáková, A.C.A. Müller, C.K. Larsen, B. Pedersen, M.R. Geiker, Towards the understanding of chloride profiles in marine exposed concrete, impact of leaching and moisture content, Construct. Build. Mater. 120 (2016) 418-431, https://doi.org/10.1016/j.conbuildmat.2016.05.069.

[110] U.H. Jakobsen, K. De Weerdt, M.R. Geiker, Elemental zonation in marine concrete, Cement Concr. Res. 85 (2016) 12-27, https://doi.org/10.1016/j. cemconres.2016.02.006.

[111] T. Das, S. Sehar, L. Koop, Y.K. Wong, S. Ahmed, K.S. Siddiqui, M. Manefield, Influence of calcium in extracellular DNA mediated bacterial aggregation and biofilm formation, PloS One 9 (2014), e91935, https://doi.org/10.1371/journal. pone.0091935.

[112] K.B. Ahmed, Etude de l'encrassement biologique de matériaux cimentaires en eau de rivière : analyse de l'influence des paramètres de surface des pâtes cimentaires, phdthesis, Université de Strasbourg, 2016, https://tel.archives-ouvertes.fr/te 1-01544842/document.

[113] K. Rajitha, Y.V. Nancharaiah, V.P. Venugopalan, Role of bacterial biofilms and their EPS on settlement of barnacle (Amphibalanus reticulatus) larvae, Int. Biodeterior. Biodegrad. 150 (2020), 104958, https://doi.org/10.1016/j. ibiod.2020.104958.

[114] J. Souche, M. Salgues, S. Pioch, K. De Weerdt, L'écoconception maritime : le paramètre matériaux, 2018, p. 10. 